Dariusz Zagórski

UMK, Toruń

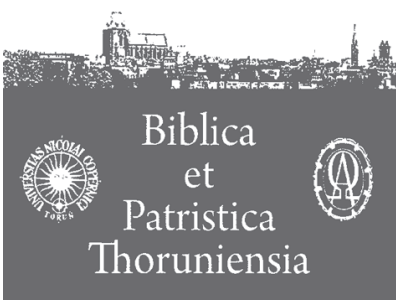

4 (2011) ISSN 1689-5150

\title{
"All people are works of the one God" The biblical teaching on the creation of man in the writings of Clement of Alexandria
}

\section{„Wszyscy ludzie są dziełem jednego Boga” Biblijne nauczanie o stworzeniu w pismach Klemensa Aleksandryjskiego}

Key words: Clement of Alexandria, Bible, creation, theology.

Słowa kluczowe: Klemens Aleksandryjski, Biblia, stworzenie, teologia.

$\mathrm{T}$ The work of Clement of Alexandria does not leave any doubt as to the beginnings of the human race. An analysis of the writings of the author show, that man was created by God ${ }^{1}$. This truth our author presents referring not only to the inspired words of the Bible, but also by consulting equally, traditional texts and those of pagan authors. "These generally few references to Greek mythology and philosophy touching upon the genesis of man confirm on the one hand the excellent knowledge of the subject by Clement, but on the other hand also his method of making use of pagan sources in leading the reader to the Christian vision" 2 .

The foundation of the latter is undoubtedly the Holy Bible, and concrete fragments taken from the first two chapters of the Book of Genesis, which deal directly with the creation of man appear in the works of Clement as many as

1 The passage contained in the title of the work has been taken from: Clemens Alexandrinus, Stromata (further citing as: Strom.) VII 86, 2. See: S. Łucarz, Grób czy świątynia? Problematyka cielesności w antropologii Klemensa Aleksandryjskiego, Kraków 2007, p. 21.

2 Ibidem, p. 22. 
thirty four times ${ }^{3}$. That is a great number of times of touching upon the Holy Texts and calling upon its authority. Therefore, it seems necessary to look upon the interpretations of the chosen passages of the recalled Book of Genesis found in the work of the Alexandrian, and likewise the ways in which they were fit into the categories of Hellenistic thinking, easier to comprehend by the majority of the contemporary recipients of the authors work ${ }^{4}$.

\section{1. "Let us make man in our own image and likeness" (Gen 1, 26)}

In Stromata Clement of Alexandria presents the before this unheard of character of difference between the meanings of the words underlining the only one of its kind share of man in the perfection of God the Creator, that is the contrasting words: "image" and "likeness":

And do some of our own not in this way ${ }^{5}$ interpret the phrase: «image», that these qualities man received immediately after birth, and the phrase «likeness», that these qualities are received later in relation to perfection? ${ }^{6}$

3 Ibidem, p. 22-23.

4 Ibidem, p. 23.

5 There is no surety as to exactly who are they that are called upon in the above cited text of Stromata: "some of our own". It may be assumed, that it possibly could be St. Ireneus of Lyon, for whom the formulation "image - likeness" fits the schema "earthly man - spiritual man". See: Irenaeus, Adversus Haereses V, 10, 12. See: M. Aubineau, Incorruptibilité et divinisation selon saint Irénée, RSR 44 (1956), p. 25-52; A. Orbe, El hombre ideal en la teología de S. Ireneo, "Gregorianum” 43 (1962), p. 449-491; S. Łucarz, op. cit., p. 45: "Whereas for Ireneus that similarity depends on the possession of a spirit $(\pi v \varepsilon v \mu \alpha)$ by man, it is Clement [...] who accents here ethical perfection". See also: H. Pietras, Rola Ducha Świętego w rozwoju ku pełni człowieczeństwa według św. Ireneusza i Orygenesa, w: Droga doskonalenia chrześcijańskiego, ed. F. Drączkowski, J. Pałucki, M. Szram, Lublin 1997, p. $118,124$.

6 Strom. II 131, 6; see also: Strom. IV 150, 2-4: „whereas the individual man receives an individual seal in accordance with the reflection in his spirit of that, which he chose. On this basis we speak also of Adam, who as a creature was perfect, for he did not lack any of these qualities, which are essential for the idea of man and his appearance. Although that, which in his development eventually received the level of perfection and through obedience was subject to justification, was strength, embodying in his masculinity, being something that was dependent on himself, his free will. God is not responsible for the fault of he who himself chose, and even more so for that, that he chose that which was forbidden. Wherefore twofold is the process of formation: first through proper generation, the second through the further development of becoming". 
This contrast does not come from the platonic tradition (as is suggested by Clement himself), also it is not found in the legacy of Philo of Alexandria. It is distinctly of biblical origin and is based on an analysis of the Book of Genesis 1,26 .

That may result from the translation of the Semitic terms: "çèlèm" and

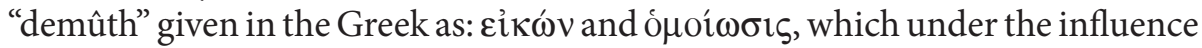
of the platonic tradition, in those times the first of those terms would give the sense of a specific share in the divinity, the second would mean a perfect spiritual likeness, which man should reach and toward which he should strive in his earthly life ${ }^{7}$.

In relation to this, Clement of Alexandria seems to discern in man two forms of perfection. The first of these, perfection in its ontological meaning, that which can be expressed with the help of the phrase: $\kappa \alpha \tau^{\prime} \varepsilon i \kappa o ́ v \alpha$, touches the idea of man. The second, wherefore, is underlined as being ethical ( $\kappa \alpha \theta^{\prime}$ o $\mu$ oí $\omega \sigma \mathrm{v})$, something similar to the potential comprehension, should be the effect of one's advancement in virtue.

The aforementioned division marked also in the works of the Alexandrian the most important goal for man. It is the likening to God "as much as

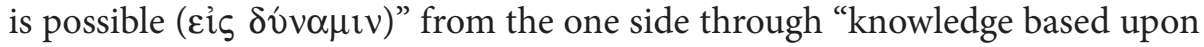
true wisdom ( $\left.\dot{\eta} \theta \varepsilon \omega \rho^{\prime} \alpha \dot{\eta} \dot{\varepsilon} \pi \imath \sigma \tau \eta \mu \nu \imath \kappa \eta\right)$ ), from the other - "practical action $(\pi \rho \hat{\alpha} \xi 1 \varsigma)$ ". In this sort of sketch of the destination of the human race there can be seen a clear accent on the valor of understanding, appearing "in Clement as a trait of the species of man"8. Clement himself gives the perfect Christian the name $\gamma \nu \omega \sigma \tau \imath \kappa o ́ s$, which besides the restricted sense of the meaning, pointing to the searching for knowledge, takes us - as is noted by $\mathrm{H}$. Crouzel - also to the term found in St. Paul: $\pi v \varepsilon v \mu \alpha \tau \imath \kappa o ́ s$, or $\tau \dot{\varepsilon} \lambda \varepsilon 10 \varsigma^{9}$. That perfection of man, his spirituality - according to the teaching of our author - compounds equally the necessity of connecting knowledge with the process of imitating Him, through

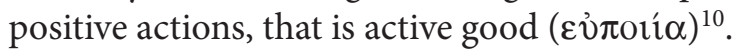

7 T. Špidlík, La spiritualità dell'Oriente Cristiano, Roma 1985, p. 50. This author on p. 51 of the cited work states that, some authors did not pay attention to the character of these different shades of meaning and did not discern between "image" and "likeness". The same is also said concerning the Cappadocian Fathers. A disputation with this view

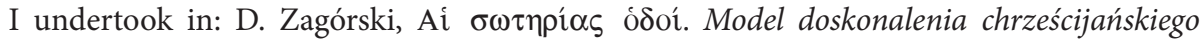
w świetle ekshortacji pastoralnych Grzegorza z Nazjanzu, Toruń 2007, p. 27.

8 J. Niemirska-Pliszczyńska, Wstęp, w: Kobierce, vol. 1, p. XXIX.

9 H. Crouzel, Szkoła Aleksandryjska i jej losy, in: Historia teologii, ed. A. Di Berardino, B. Studer, vol. 1: Epoka patrystyczna, Kraków 2003, p. 202; S. Łucarz, op. cit., p. 52.

10 J. Niemirska-Pliszczyńska, Wstęp, w: Kobierce, vol. 1, p. XXIX. 
In the presented above interpretation of the biblical picture of the creation of man, his likeness to the Creator, a special place and meaning is going to be had in the teaching of Clement the recalled earlier gnostic ( $\gamma \nu \omega \sigma \tau \imath \kappa o ́ s)$. The Alexandrian notices, that among all people, it is he who is in the greatest level the image of God:

"That is what the one is like, «in the image and likeness» (Gen 1,26), the gnostic, who imitates God, as much as is possible, who does not disregard anything which might make possible that likeness, living temperately, is persistent, acts justly, rules like a king over his passions, is inclined to give that which he has, in accord with his strength, willingly offers support with word and deed. That man «is great - says the Scriptures - in the kingdom, who so acts and teaches» (Mt 5, 19), imitating God in this, that he imparts good things similar to Him"11.

The presented outline of the life and functioning of the gnostic found in Stromata is nothing other than a meticulous "elucidation" on the question of the perfection of man with the goal of actualizing the coming closer to God of the greatest possible number of Christians ${ }^{12}$. Clement in his teaching presents the gnostic as a man, who through his suppositions should become "truly spiritual" and "consistent" 13 . He remains - in the opinion of our author - unreachable by all forms of thought which come about from passion and lust. Referring to the earlier discussed passage of the Book of Genesis 1, 26 the Alexandrian defines him with the title of "a man fully finished «in the likeness of God» (Gen 1,26), like a statue"14. The first imperative of his actions becomes a lack of self-interest, and the goal - that way of completing life, which would be contained within the borders of image and likeness marked out by God in the Book of Genesis:

This is the first imperative in the good actions of the perfect man: being that if does something good it is not with the aim of his own personal benefit, but when as the result of deep experience, that doing good is moral beauty, all of his ability for action, in a state of creative tension, is turned towards good in all actions, and not that sort which is in one case good and in another not, but strongly based upon a permanent disposition to doing good not for renown, or as the philosophers say, for good praise, or for payment from either man or God. Wherefore, the gnostic

11 Strom. II 97, 1-2.

12 As is rightly noted by S. Łucarz, the earlier recalled "limitation of perfection to the ontological and ethical has its beginnings in the fact that, man in distinction from all the rest of creation was created as a free being". See: S. Łucarz, op. cit., p. 46.

13 Strom. III 69, 4.

14 Strom. III 69, 4. 
should fulfill his life «in the image and likeness» (Gen 1,26) of the Lord. And even if in the doing of good itself something stands as a hindrance, he discourages all revenge, forgetful of evil and as if numb, shows justice and goodness equally «in relation to the just and unjust» $(\text { Mt } 5,45)^{15}$.

The perfect Christian's likeness to God is confirmed in every situation of life. He is not hindered in this by the functions he fulfills and the offices he holds. As Clement notes - in the just soul "is erected the holy seat of the Ruler of everything, that which is mortal and that which is immortal, the King and Creator of all moral beauty [...], [who] compresses on the soul of the gnostic a perfect picture according to his own image (Gen 1,26), as like a stamp" ${ }^{16}$. That therefore causes, that when he takes up power or leadership, he will rule with consideration for the good of the people under him while eradicating however, indulgence and making use of the necessary means of training in regards to people who are bad and vicious ${ }^{17}$.

References to the biblical account of the creation of man from Gen 1,26 are present equally in others works of the Alexandrian. Noteworthy in this respect is the first book Paedagogus, which encourages the faithful, who are still far from the perfection of the gnostic life (presented earlier in Stromata) to undertake the efforts connected with advancement towards spiritual immaculateness. Clement decidedly calls to the loving of God, who longs to lead the Christian to the good life and encourages conforming actions in accord with His will. That is to lead to the realization in man in a full way the pronouncements of the Holy Text from the Book of Genesis about the "image and likeness"18.

Similarly interesting also appears to be the teaching of the author contained in the second and third books of the earlier recalled work of the Alexandrian. These are concrete directions, dealing with the everyday life, a sort of "savoir vivre" of Christian action. One of the examples can be taken from the reply of our author directed to women, criticizing all forms of action connected with beautifying oneself. Clement of Alexandria clearly opposes these practices, underlining the value of "art" which is found in the works of creation, coming from God, markedly different from the "art of man", so much farther from imperfect:

15 Strom. IV 137, 1-3.

16 Strom. VII 16, 5-6.

17 Strom. VII 16, 4-5.

18 Clemens Alexandrinus, Paedagogus (further citing as: Paed.) I, III, 9, 1. 
It is not right that those, who have been made «in the image and likeness of God» (Gen 1,26), should be as throwing away their archetype make use of some foreign art for the service of beautification, preferring a bad human art in the place of the divine creative art. The Pedagogue [Christ] commands that woman conduct themselves in «dignified clothing and dress with modesty and wisdom» (1 Tim $2,9)$, «being obedient to their husbands, in order that even if some them are not obedient to the Word, they may be saved through the behavior of their wives, without words, meditating on - says the Scriptures - your pure behavior and fullness of respect» $(1 \text { Pet } 3,1-4)^{19}$.

\section{2. "Given to man as a helper" (Gen 2, 18-24)}

Clement of Alexandria in Paedagogus presents criticism of men who beautify their looks. Using excessive description ${ }^{20}$ he calls for men to discard this typical for women way of acting, reminding them of the dignity that they received from the Creator Himself. In the opinion of our author the man is "older" than Eve and constitutes the symbol of a better nature. Whereas woman was given to him as a "helper" (Gen 2, 18), "well adapted for the reception of the seed, [...] so that she might give birth to offspring and manage the house" 21 .

The Alexandrian, having in mind the entire time the words from the Holy Text above, does not refrain either in his judgment of women. Being a helper to man is regarded by Clement as being a very significant obligation, which is why the earlier mentioned beautifying of that which is natural, is not accepted by him, especially if it is driven to absurd, becoming humorous and worthy of pity:

I am embarrassed of the woman, who has become the subject of comedy, the woman who was fashioned as a «helper» for man, and ends up destroying that ${ }^{22}$.

Clement of Alexandria many times more refers to the passage from Gen 2, 18-24, among others then, when he describes in his Stromata the ideal wife, who should love her husband and support him in all the circumstances of life. Once again, the Biblical text in an excellent way is harmonized with the declarations of pre-Christian authors, so that in the classically formed intellects of many Alexandrian Christians it might be able to easier comprehend the truths flowing from Divine Revelation.

\footnotetext{
19 Paed. III, XI, 66, 2-3.

20 Paed. III, III, 15, 1.

21 Paed. III, III, 19, 1.

22 Paed. III, II, 8, 1.
} 
The first of the authorities which is called upon by Clement is Euripides. This author, it seems, according to the Alexandrian, impeccably details the text of the biblical message, filling it with, in harmony with the tenets in force at that time, his own particular accentuation. The helpfulness of the woman in relation to the man, in the opinion of the tragedy writer, should materialize in subordination and in the sharing with him of his sorrows and pains. She should stand by him equally in prosperity, and likewise in unhappiness and sickness:

«Whatever the husband says, she should acknowledge as good, even if it is bad, Strive to say only, that for which her husband is pleasant».

$[\ldots]$ «Beautiful it is, when for the husband it is bad, that the wife even if at that time She be sad, should be sharing his pleasure, and likewise pain ${ }^{23}$.

Clement fully accepts that teaching, adding still the agreement of marital relations with the will of the Logos, that is the subordination of the physical bond of the spouses to God and the keeping of it "«in a state of fervor and unwavering certainty of faith ${ }^{24}$. Important also is the reference to the currently discussed passage of the Scriptures that we find in the third book of Stromata, in the borders of which the Alexandrian presents his views against heretical teaching depreciating the value of the marital bond. In opposition to the ideologies staying in the two extremes, that is the avoidance of marriage out of hatred to the Creator and the using of it for undignified passions, Clement teaches about the correct understanding of the bond between two people, reminding about the common responsibilities of the spouses and the dignity of the human body.

The Alexandrian evoking the biblical teaching (1 Cor 7, 3; 5), encourages marital relations, in order that Satan might not tempt man, using his unrestraint $(1$ Cor 7,5$)$, he summons, further using the words of the inspired text (1 Cor 7 , 3 ), to the mutual fulfillment of responsibilities toward one another, in which he recognizes the special role of the woman, given to the man, in accord with the words of Gen 2, 18, as a "helper"25. That support - in the opinion of our author -

23 Strom. IV 125, 1-2. The above cited verses are contained in: Tragicorum Graecorum fragmenta, A. Nauck, Lipsiae 1926 (2), Euripidis incertarum fabularum fragmenta 909, 7-12, p. 653.

24 Strom. IV 126, 1.

25 Strom. III 108, 1. See also: Strom. 82, 3-4. To those, who as an argument against marriage cited the fact that Christ was unmarried, Clement directs the following words (Strom. III 49, 1-4): "There are those, who call marriage simply prostitution and hold that, it was conveyed by the devil. And in their pride proclaim that, they are the only ones who 
extends not only to the sexual sphere, linked with the procreation of offspring, but also to the governing of the household, but also in the furnishing of help to the husband in the "area of faith in Jesus Christ"26. The importance of this helpfulness the Alexandrian underlines very clearly, accenting on this occasion the rule of indissolubility of the bond, so strongly expressed in the already cited 1 Letter of St. Paul to the Corinthians (7, 10-12. 14). Useful in the teaching of our author becomes also the 1 Letter of St. Paul to Timothy, commanding the transmitting of direction of the Church to that kind of bishop who "knows well how to direct his own household"27, which is that type, who creates a union with only one woman ${ }^{28}$.

\section{3. "Increase and multiply in number" (Gen 1, 28)}

Clement of Alexandria emphasizes, that the creation of man ought to be identified as a onetime act, not repeating again. It is true that he accentuates the cooperation of people in the calling of new life into existence, he reminds however, that "that power of giving life varies [...] in an essential way from the power to create"29, whereas man can himself only be classified as the procreator of new life, and that is by God conferred and a gift ${ }^{30}$.

Our author teaches that humans are in this way the image of God, in that they may cooperate with Him in the birth of man. This particular and special task is given however, only to those people who are living in the marriage union. Its destination is the bearing of offspring, whereas its goal is the possession of children who are beautiful and good ${ }^{31}$.

imitate the Lord, who neither married, and likewise possessed nothing material in this world. They boast also that they, better than others understood the Gospel. To them the Scriptures reply in these words: «God acts against the plans of the prideful, giving grace to the humble» (Prov 3, 34; Jas 4, 6; 1 Pet 5, 5). They do not know then, why the Lord did not marry? Firstly, because He had His Bride - the Church; secondly because He was not an ordinary man, that He should need a corporeal helper (Gen 2, 18). Equally, He also had no need of begetting children, as being eternal, and likewise being the only begotten Son of God".

26 Strom III 108, 1.

27 Strom. III 108, 2.

28 Strom. III 108, 2.

29 S. Łucarz, op. cit., p. 85.

30 Ibidem.

31 Paed. II X 83, 1. 
The meditations of the author contained in the Paedagogus, besides the clear directions of an ethical nature dedicated to those people who are undertaking life in the marriage union, present the receiver of the work of the Alexandrian also with very strong opposition, in the area of the cooperative power of man directed towards the giving of birth, to all forms of perversion, especially homosexuality, classified as a form of relations contradictory to nature ${ }^{32}$.The male seed is meant for the prolonging of life, the same undertaking of cooperation in the procreation of man, may not in the opinion of our author be wasted or treated badly. It is the substance which is found at the beginning of life and which possesses united within itself the idea in relation to nature ${ }^{33}$.

To the discussed passage from the Book of Genesis the Alexandrian refers to still many more times. He does this particularly in the context of the earlier recalled hetero-doctrinal groups, of which there are those of the first group who abstain from marriage because they consider reproduction to be an evil thing, and the birth of children they see as a punishment, the second group on the other hand practice all forms of licentiousness and debauchery.

In regards to the first category of erroneous believers, Clement speaks principally against the followers of Marcion ${ }^{34}$. Our author turns their attention to the lack of conformity between that model of life and nature and points to the many inconsequentialities, and also the inconsistencies found in that teaching:

"The followers of Marcion, assumed that the multiplication of the human race is a bad thing, $[\ldots]$ whereas the nature of man is evil, being a result of the union of evil matter and the just God Creator. As a result of that view they do not wanting to permit that the world should be peopled, [...] they prefer to abstain from marriage. [...] But these people, who in their godless rebellion against have fallen away from reasoning in accord with nature and also despise the indulgence and goodness of God, nevertheless - even though they do not want to marry - they are using the created by God means of sustenance and breath the air of the Creator of the entire world, for they are His work and exist in that, which is His own personally. They preach $\gamma v \hat{\omega} \sigma 1 \varsigma$ that is «foreign", according to their own definition, as their gospel, and nonetheless they should be showing gratitude to the Lord of this world, that they here may preach their «Good News»"35.

Lack of doctrinal uniformity and errors in understanding Clement also sees similarity in the teachings of a sect of a radically licentious character. In this

32 Paed. II X 83, 3.

33 Ibidem.

34 Strom. III 12, 2.

35 Strom. III 12, 1-3. 
case he points to the opposition of the heretics to the Divine Law, in way that is however choosy and inconsequential:

"If at any rate you want to abolish the commandments of the Giver of Law, then why do you struggle to abolish in particular the commandment: «Thou shalt not commit adultery» (Ex 20,14), "Thou shalt not make boys to be unclean» and others, which deal with restraint? Why do you not rather attempt to destroy winter, for that also is the work of His hand, so that still during the time it continues you might bring about summer, or why do you not struggle to make the earth navigable and the sea so that it might be possible to cross it with dry feet (see 2 Macc 5, 21) - similarly as, according to the stories of the historians, wanted to accomplish the barbarian Xerxes. And why do you not oppose all of the commandments? For when He said: «multiply and grow in number» (Gen 1,28; 9, 1), you should in order to oppose Him discourage all sexual life in general. And when He said: «I have given you everything for food and for you to make use of» (Gen 1, 29; 9, 2), you should use nothing"36.

An important place in which Clement refers to the biblical command from the Book of Genesis 1,28, is the passage of Stromata presenting the teaching about "the aims and rights of marriage". The Alexandrian, calling upon in it of various points of view of ancient authors and philosophers, seems to accept only those among them, in which relations between two people are in agreement with the rigidly outlined in his teaching criteria of temperance. In this context, equally the words of the Holy Text speaking about "being fruitful and multiplying" should be properly interpreted, that is especially by taking into consideration the intelligence of human nature:

Finally the advocates of the institution of marriage say: «Nature herself has made us inclined to marriage», as is a result of the physical structures of man and woman and likewise the testimony: «Be fruitful and multiply» (Gen 1,28), on which the persistently bring up. Even if things are so, they should acknowledge it to be an affront for man, that being the work of the Creator Himself they show less restraint than irrational creatures, which do not practice relations with numerous partners, negligently, but only with one partner, and that being of the same species, just as things are with pigeons, ringdoves, turtledoves and the like ${ }^{37}$.

Therefore, it is necessary to remove from marital relations everything, which the practice of dirties and dishonors the union, so that we may not be accused that the pairing of irrational creatures is more in agreement with nature, in the area of the agreed goal, than copulation of people ${ }^{38}$.

\footnotetext{
36 Strom. III 36, 5-37, 2.

37 Strom. II 139, 3-5.

38 Strom. II 143, 3.
} 


\section{Summary}

Clement of Alexandria in his teaching on anthropology and in particular on creation of man which is discussed in this paper combines the orthodox teaching of Scriptures with various philosophical currents and traditions. The biblical description of the creation of man is for him a clear and sufficient presentation. However, for his teaching he does not hesitate to enrich it with "grains of truth" found in philosophy. Analyzing the first two chapters of the Book of Genesis he emphasizes the dignity of man and his special destiny. The biblical passages of the Book of Genesis are also incorporated into the didactic communications of the wise man, especially in relation to the marital life, being so very much attacked and discredited in his time.

\section{Streszczenie}

Klemens Aleksandryjski w prezentowanej przez siebie antropologii, także w omawianym przez nas temacie stworzenia człowieka, w nieustanny sposób łączy z sobą wątki czystego i nieskażonego nauczania Pisma (w ramach którego przewodnikiem i prowadzącym jest Boski Logos) z różnymi nurtami i tradycjami filozoficznymi.

Opis stworzenia człowieka odnajdywany w Biblii jest dla aleksandryjczyka, jako chrześcijanina, przedstawieniem wyczerpującym i niepodważalnym. Włączenie jednak do swego nauczania odnajdywanych w filozofii „ziaren prawdy” pełnić ma rolę akomodacyjną, przybliżającą współczesnym Klemensowi Grekom „trącący mitem” tekst Pisma.

Omawiane w dziełach naszego autora wybrane passusy z pierwszego i drugiego rozdziału Księgi Rodzaju, wskazują wyraźnie na godność człowieka i jego szczególne przeznaczenie. Jest on dziełem Boga chcianym i zaplanowanym przewyższającym pozostałe stworzenia, jest tym, w którym złożony został Boży obraz i w końcu tym, któremu zadane zostało upodobnienie się do Stwórcy przez doskonalenie i postęp w wierze.

Passusy biblijnej Księgi Genesis wykorzystane tez zostają w dydaktycznym przekazie mędrca, zwłaszcza odnoszącym sie do życia małżeńskiego, tak bardzo atakowanego w tym czasie i dyskredytowanego. 